\title{
Clinical Features and Management of Secundum Atrial Septal Defect in Infants and Children
}

\author{
Bambang Madiyono, Jumiety Achmad, Sudigdo Sastroasmoro, Ismet N. Oesman, Sukman Tulus Putra
}

\begin{abstract}
Abstrak
Dalam penelitian retrospektifini dilakukan evaluasi terhadap penampilan klinis dan tata laksana pasien defek septum atrium yang berobat di Subbagian Kardiologi, Bagian Ilmu Kesehatan Anak RS. Cipto Mangunkusumo, Jakarta, antara 1 Januari 1983 sampai dengan 31 Desember 1992. Sebelum tersedia alat ekokardiografi, diagnosis defek septum atrium semata-mata didasarkan pada riwayat penyakit, pemeriksaan fisis, elektrokardiogram, dan foto rontgen dada. Setelah tersedia alat ekokardiografi (Januari 1987), diagnosis kelainan ini dipastikan dengan ekokardiografi (kemudian juga Doppler dan Doppler berwarna). Seri ini menunjukkan: (1) Defek septum atrium sekundum lebih sering ditemukan pada anak perempuan, dengan rasio perempuan : lelaki $=1,5: 1,2 ;(2)$ Jumlah pasien yang didiagnosis sebagai defek septum atrium lebih banyak setelah tersedia alat ekokardiografi; (3) Penemuan klinis dan pemeriksaan penunjang yang khas lebih sering didapatkan pada pasien berusia 3 tahun atau lebih dibanding dengan yang berusia kurang dari 3 tahun; (4) Hambatan pertumbuhan, kardiomegali, dan right branch block lebih sering ditemukan pada defek besar; (5) Pengobatan terpilih adalah operasi penutupan defek, yang dapat dilakukan tiap saat.
\end{abstract}

\begin{abstract}
This retrospective study aimed to review the clinical features and management of patients with secundum atrial septal defect (ASD $\left.2^{\circ}\right)$. The subjects studied were 90 boys (39.8\%) and 136 girls (60.2\%), treated at the Outpatient Clinic, Cardiology Division, Department of Child Health, Cipto Mangunkusumo Hospital, Jakarta, Indonesia, from January 1, 1983 to December 31, 1992. Clinical assessment and management were evaluated by one of the authors. Electrocardiographic, radiographic, and hemodynamic findings were analyzed by the experts. The diagnostic procedure was completed with echocardiographic examination since January 1987. This study discloses several findings: (1) ASD $2^{\circ}$ affected girls more than boys, the sex ratio was $1,5: 1 ;$ (2) The diagnosis of $A S D 2^{\circ}$ in infants was increased afier the advent of echocardiography; (3) While typical auscultatory findings could be heard in older ASD cases, the clinical features were not specific in young infants; (4) Growth retardation, cardiomegaly and right bundle branch block were common in large ASD $2^{\circ}$; (5) Simple closure of ASD $2^{\circ}$ was the procedure of choice.
\end{abstract}

Keywords: atrial septal defect, echocardiography, clinical manifestations

Secundum atrial septal defect $\left(\operatorname{ASD} 2^{\circ}\right.$ ) is the third or fourth most common congenital heart disease in childhood, accounting for approximately 7 percent of all children with congenital heart disease. ${ }^{1-3}$ Most infants with this defect are asymptomatic, and frequently their condition goes undetected until school age. Most patients with a moderate left-to-right usually complain only of mild fatigue and dyspnea. The frequency of fatigue and dyspnea increases in infants with large shunt, and cardiac failure occasionally occurs. ${ }^{5}$

$\operatorname{ASD} 2^{\circ}$ is easily recognized in older patients by the typical auscultatory findings consisting of widely fixed

Department of Child Health, Medical School, University of Indonesia, Jakarta, Indonesia

Paper presented at the 9 th Indonesian Congress of Pediatrics, June 13-17, 1993, Semarang, Indonesia. second heart sound and soft ejection systolic murmur at the upper left sternal border. ${ }^{4,6,7}$ In young infants with $\operatorname{ASD} 2^{\circ}$ the clinical findings are usually not specific, ${ }^{8-12}$ echocardiographic examination is usually needed to confirm the diagnosis. ${ }^{13-16}$

The purpose of this study was to review the physical as well as electrocardiographic, radiographic, and echocardiographic findings of patients with ASD $2^{\circ}$ treated at our Outpatient Pediatric Cardiology Clinic during the last 10 years.

\section{METHODS}

This retrospective study reviewed the clinical findings and management of patients with $\operatorname{ASD} 2^{\circ}$ treated at the Outpatient Clinic, Cardiology Division, Department of Child Health, Cipto Mangunkusumo Hospital, Jakarta, 
Indonesia, from January 1, 1983 to December 31, 1992.

Before echocardiographic machine was available in our department, the diagnosis of ASD was based on typical clinical symptoms and signs, electrocardiogram, and chest X-ray examinations. Since January 1,1987 , when electrocardiograhic machine was available, the diagnosis was confirmed by echocardiographic examination. Cardiac catheterization was only performed on certain indications prior to surgical closure.

Suggestive diagnosis of ASD by the referring physicians was noted. Clinical symptoms such as recurrent respiratory tract infections (more than 4 episodes per year), easy fatigability (as reported by the parents), dyspnea on exertion, and growth retardation (weight per age, NCHS standard) were recorded. Physical examination was thoroughly carried out by an experienced staff. Signs of typical auscultatory findings of ASD $2^{\circ}$, i.e., widely fixed second heart sound and ejection systolic murmur were noted by one of the authors.

Complete electrocardiogram was recorded in all cases, i.e., standard leads, unipolar limb leads and chest leads $V_{3} R, V_{1}-V_{6}$. All electrocardiograhic tracings were reviewed and assessed by the authors. Heart size was evaluated roentgenographycally by measuring the cardio-thoracic ratio, i.e., the ratio of the maximum width of the heart to the body thorax at the level of the right diaphragm in antero-posterior view. M-mode and two dimensional echocardiograms were performed in all patients seen after January 1, 1987 using ALOKA SSD 720. The echocardiographic examination was completed by color Doppler echocardiography using ALOKA SSD 870. Cardiac catheterization was performed prior to surgery in some special cases with suggestive pulmonary hypertension.

The patients were arbitrarily divided into two groups; Group A consisted of patients admitted during the first four-year period (from January 1, 1983 to December 31,1986 ), where echocardiography was not available, while Group B comprised the rest of patients admitted afterward.

For statistical analysis numerical results are given as mean (standard deviation of the mean). Quantitative data were compared by Student's $t$. A value of $p<0,05$ was considered statistically significant.

\section{RESULTS}

Two hundred and twenty six patients were enrolled in the study. They were 90 boys $(39.8 \%)$ and 136 girls $(60.2 \%)$. The female to male ratio thus being $1.5: 1$, so ASD $2^{\circ}$ affected girls more than boys as is generally the case. ${ }^{1-4}$

The diagnosis of ASD had already been suggested by the referring physicians in 62 cases $(27.4 \%)$, most of them aged 3 years or more. This relatively small percentage indicates that $\mathrm{ASD} 2^{\circ}$ could be recognized by the referring physicians in some older cases.

The distribution of patients studied based on the age group at the first evaluation showed bimodal pattern (Table 1), the two peaks were at the age group of less than 1 year $(30.5 \%)$ and $3-6$ years $(29.2 \%)$, respectively.

Table 1. Sex and age distribution of 226 ASD $2^{\circ}$ patients

\begin{tabular}{ccc}
\hline Age (years) & Number of Cases & Percentage \\
\hline $0-$ & 69 & $(30.5 \%)$ \\
$1-$ & 51 & $(22.6 \%)$ \\
$3-$ & 66 & $(29.2 \%)$ \\
$7>$ & 40 & $(17.7 \%)$ \\
\hline Total & 226 & $(100.0 \%)$ \\
\hline
\end{tabular}

Table 2 depicts the number of patients by age, based on 5 year-period of study. It is clear that the number of patients with $\operatorname{ASD} 2^{\circ}$ increased in the last 5 years ( 144 cases or 25 cases per year), compared with the number of patients in the second 5-year period ( 82 patients, or 17 cases per year). This table also shows that the proportion of ASD patients less than 3 years of age increased from $41.5 \%$ in the first 5 -year period to $59.7 \%$ in the second 5 -year period.

Table 2. Age distribution of 226 patients based on 5-year period of diagnosis

\begin{tabular}{cccc}
\hline Age (years) & $1983-1987$ & $1988-1992$ & Total \\
\hline$<3$ & $34(41.5 \%)$ & $86(59.7 \%)$ & $120(53.5 \%)$ \\
3 or more & $48(58.5 \%)$ & $58(40.3 \%)$ & $106(46.5 \%)$ \\
\hline Total & $82(100.0 \%)$ & $144(100.0 \%)$ & $226(100.0 \%)$ \\
\hline
\end{tabular}


Further interesting result is seen if the age distribution of patients studied was related with the availability of echocardiographic machine. The number of patients with ASD $2^{\circ}$ in this series was increased significantly, i.e., 49 patients in the first 4 years (12 cases per year) compared with 177 patients in the last six years (30 cases per year). See Table 3 . The proportion of ASD patients diagnosed before the age of 3 years increased from $28.6 \%$ during $1983-1986$ to as high as $59.9 \%$ in the period of $1987-1992$.

Table 3. Age distribution of 226 patients based on echocardiographic availability

\begin{tabular}{ccrc}
\hline Age (years) & $\begin{array}{c}1983-1986 \\
\text { (without echo) }\end{array}$ & $\begin{array}{r}1987-1992 \\
\text { (with echo) }\end{array}$ & Total \\
\hline$<3$ & $14(28.6 \%)$ & $106(59.9 \%)$ & $120(53.5 \%)$ \\
3 or more & $35(71.4 \%)$ & $71(40.1 \%)$ & $106(46.5 \%)$ \\
\hline Total & $49(100 \%)$ & $177(100 \%)$ & $226(100.0 \%)$ \\
\hline
\end{tabular}

The clinical symptoms and signs of the 226 patients with ASD $2^{\circ}$ are shown in Table 4 . The patients were arbitrarily divided into 2 groups, i.e., those aged less than 3 years and those aged 3 years or more. The division was based on the assumption that at the age of 3 years the clinical presentations of ASD, if any, usually have manifested. It is seen that the percentage of the clinical manifestations in group of patients aged 3 years or more was consistently higher than that of patients aged less than 3 years. Marked differences was found in dyspnea on exertion $36.8 \%$ in group of patients 3 years old or more vs $15.5 \%$ in group of patients less than 3 years), growth retardation (43.3\% vs $26.7 \%$ ), palpable thrill ( $17.0 \%$ vs $0 \%$ ), widely fixed second heart sound ( $96.2 \%$ vs $43.3 \%)$, ejection systolic murmur (100\% vs $57.5 \%$ ), and diastolic flow murmur (26.4\% vs $0 \%)$.

The results of supporting examinations are presented in Table 5. In this table patients were also arbitrarily divided into 2 groups, i.e., those aged 3 years or more, and those aged less than 3 years old. Similar to those of the clinical findings, we also noted that typical findings for ASD were more commonly found in older patient group when compared with those in younger patients. Notable difference was noted in the prolongation of P-R interval $56.6 \%$ in group of patients 3 years of age or more vs $3.3 \%$ in those aged less than 3 years), incomplete bundle branch block $(90.6 \%$ vs $30.8 \%)$, right ventricular hypertrophy $(89.6 \%$ vs $33.3 \%$ ). Cardiothoracic ratio of more than $55 \%$ and increased vascular markings were 2 times as much in the group of patients aged 3 years or more as in the younger age group. With echocardiograms, the atrial septal defect could be seen in all subjects examined (106 patients in group less than 3 years of age and 71 patients in the older group). Right atrial and ventricular dilatations were also noted more frequently in the older age group. Of particular interest was that we did not find a clear paradoxical septal motion in the M-mode of patients less than 3 years of age, but did so in $32.1 \%$ of patients aged 3 years or more.

Table 4. Physical findings of the 226 patients studied

\begin{tabular}{|c|c|c|c|c|c|c|}
\hline & \multicolumn{6}{|c|}{ Age } \\
\hline & \multicolumn{2}{|c|}{$<3$ yrs $(\mathrm{N}=120)$} & \multicolumn{2}{|c|}{3 years or more $(\mathrm{N}=106)$} & \multicolumn{2}{|c|}{ Total $(\mathrm{N}=226)$} \\
\hline & $\mathrm{n}$ & Percent & $\mathrm{n}$ & Percent & $\mathrm{n}$ & Percent \\
\hline Dyspnea on exertion & 21 & 14.5 & 39 & 36.8 & 60 & 26.6 \\
\hline Recurrent respiratory tract infection & 46 & 38.3 & 99 & 93.3 & 145 & 64.2 \\
\hline Tachycardia & 68 & 56.7 & 59 & 55.7 & 119 & 52.8 \\
\hline Growth retardation & 32 & 26.7 & 46 & 43.3 & 78 & 34.5 \\
\hline Right precordial bulging & 12 & 10.0 & 33 & 31.3 & 45 & 19.9 \\
\hline Right precordial heaving & 8 & 6.7 & 20 & 18.9 & 28 & 12.4 \\
\hline Thrill & 0 & 0 & 18 & 17.0 & 18 & 8.0 \\
\hline Pulmonary tapping & 0 & 0 & 10 & 9.4 & 10 & 4.4 \\
\hline Accentuated first heart sound & 0 & 0 & 3 & 2.8 & 3 & 1.3 \\
\hline Widely fixed split 2 nd heart sound & 52 & 43.3 & 102 & 96.2 & 157 & 69.5 \\
\hline Accentuated P2 & 0 & 0 & 10 & 9.4 & 10 & 4.4 \\
\hline Ejection systolic murmur & 69 & 57.5 & 106 & 100 & 175 & 77.4 \\
\hline Mid diastolic tricuspid flow murmur & 0 & 0 & 28 & 26.4 & 28 & 12.45 \\
\hline
\end{tabular}


Table 5. Results of ECG, Chest X-ray, and echocardiohraphic examination in 226 patients studied

\begin{tabular}{|c|c|c|c|c|c|c|}
\hline & \multicolumn{6}{|c|}{ Age } \\
\hline & \multicolumn{2}{|c|}{$<3$ yrs } & \multicolumn{2}{|c|}{3 yrs or more } & \multicolumn{2}{|c|}{ Total } \\
\hline & $\mathrm{n}$ & Percent & No & Percent & No & Percent \\
\hline ECG & \multicolumn{2}{|c|}{$(n=120)$} & \multicolumn{2}{|c|}{$(n=106)$} & \multicolumn{2}{|c|}{$(\mathrm{N}=226)$} \\
\hline - Right axis deviation & 36 & 30.0 & 57 & 53.8 & 93 & 41.4 \\
\hline - Prolonged PR interval & 4 & 3.3 & 60 & 56.6 & 64 & 28.5 \\
\hline - IRBBB & 37 & 30.8 & 96 & 90.6 & 133 & 58.9 \\
\hline - Right atrial enlargement & 8 & 6.7 & 39 & 36.8 & 47 & 20.8 \\
\hline - Right ventricular dilatation & 40 & 33.3 & 95 & 89.6 & 135 & 59.7 \\
\hline CXR & \multicolumn{2}{|c|}{$(n-120)$} & \multicolumn{2}{|c|}{$(n=106)$} & \multicolumn{2}{|c|}{$(\mathrm{N}=226)$} \\
\hline - CTR > 0,55\% & 24 & 20.0 & 70 & 66.0 & 94 & 41.4 \\
\hline - Increased vasc markings & 38 & 31.7 & 68 & 64.2 & 106 & 47.4 \\
\hline Echocardiogram & \multicolumn{2}{|c|}{$(n=106)$} & \multicolumn{2}{|c|}{$(n=71)$} & 180 & 80.1 \\
\hline - Visualized defect & 106 & 100.0 & 71 & 100.0 & 177 & 100.0 \\
\hline - Right atrial enlargement & 65 & 61.3 & 60 & 84.5 & 125 & 69.1 \\
\hline - Right ventric. hypertrophy & 70 & 66.0 & 64 & 90.1 & 134 & 74.0 \\
\hline - Paradoxical septal motion & 0 & 0.0 & 34 & 47.8 & 34 & 15.0 \\
\hline
\end{tabular}

We performed cardiac catheterization in 36 out of the total 226 patients. Most of them (27) are performed before echocardiography was available. After echocardiographic examination was available, we did cardiac catheter only in patients who showed evidence of pulmonary hypertension. Surgical closure of the ASD was perfomed in 47 patients, with the mortality of 8.5\%. See Table 6 .

Table 6. Invasive diagnostic procedure and surgical cases

\begin{tabular}{lr}
\hline Cardiac catheterization & $36(15.9 \%)$ \\
Simple ASD closure & $47(20.8 \%)$ \\
Surgical mortality & $4(8.5 \%)$ \\
\hline
\end{tabular}

\section{DISCUSSION}

This series shows that girls were more affected than boys, and there was a bimodal age distribution of patients with ASD $2^{\circ}$. These findings were similar to those reported by by Fyler. ${ }^{3}$ A survey of hospitalized patients in the past 2-3 years shows a bimodal age distribution of patients admitted with congenital heart disease. Infants newly discovered to have a cardiac problem constitute one group, whereas older children contribute to the second peak. ${ }^{3}$

The incerase number of patients in our series, i.e., more patients diagnosed of having $\operatorname{ASD} 2^{\circ}$ in second 5-year period, has also been noted by other investigators. The rank order of cardiac defects seen at the Children's
Hospital in Boston reflecting the recent increase in atrial septal defects, probably related to local interests in closing these defects with devices introduced during cardiac catheterization. ${ }^{3}$ We can say with confidence that the marked increase in the number of patients diagnosed as having ASD $2^{\circ}$ in the last 5 years is closely related to the availability of echocardiographic examination. Similarly, the incerased number of patients aged less than 3 years in our series must have been related to echocardiography.

Our data also support previous knowledge that ASD patients aged less than 3 years of age are usually asymptomatic, and also give only non-specific clinical signs. ${ }^{8-12}$ Typical auscultatory findings for ASD which are consisted of widely fixed second heart sound and soft ejection systolic murmur are usually noted when the patients becoming older, so that prior to echocardiography era, the diagnosis of ASD is usually established in the preschool age group (3-5 years). The wide split of the second heart sound results from delayed emptying of the overload right ventricle; the fixed split is the consequence of unlimited communication between the two atria, allowing for equalization of the influence of respiratory variation on the right and left ventricular output. ${ }^{3}$

Other non-specific findings in ASD include right precordial bulging and right precordial heaving. These are correlated with right ventricular volume overload with large left to right shunt at atrial level. This abnormality is usually found when the overload become 
chronic; in the case of ASD, older children have the higher probability to have this sign, as seen in our series.

Mid-diastolic murmur at the lower left sternal border, whis is considered to be associated with relative tricuspid stenosis was detected only in 28 cases (12.4\%). This relatively small percentage of mid-diastolic murmur was due to the absence of such sign in the younger age group. From the clinical point of view, the presence of this murmur usually indicates that there is a large left to right shunt. ${ }^{3,4,7}$

Atrial septal defect rarely results in congestive heart failure in infancy. Congestive heart failure was suspected on the basis of tachypnea, tachycardia, and cardiomegaly. Early changes in right ventricular compliance combined with ASD can lead to early diastolic overloading of the right ventricle causing cardiomegaly and congestive heart failure at an early age. ${ }^{10} \mathrm{His}-$ tory of frequent respiratory infections was reported in most patients. ${ }^{10}$ We did not diagnose a single ASD patient with frank congestive heart failure; however, a substantial number of patients, especially those aged 3 years or older, showed growth retardation. This indicated that the left to right shunt had disturbed the normal hemodynamic, which caused in decreased intake of the nutrients. ${ }^{17-20}$ Patients with complicated ASD showed marked retardation in both height and weight; whereas those with isolated ASD $2^{\circ}$ showed only slight retardation in height, but moderate retardation in weight. ${ }^{7}$

Pulmonary hypertension as a consequence of ASD $2^{\circ}$ develops rarely in chilhood. ${ }^{21}$ Pulmonary tapping and accentuated $\mathrm{P}_{2}$ as signs of pulmonary hypertension that may develop in untreated patients were found in 10 cases $(4.4 \%)$, all of them belonged to the older age group. These findings were confirmed on cardiac catheterization.

Abnormal electrocardiogram are usually seen in ASD $2^{\text {o }}$. $^{1-3}$ However, this abnormality is more commonly seen in older patients, as also seen in our series. In this series incomplete right bundle branch block was found in 133 cases $(58.9 \%$ ) (Table 7). Incomplete right bundle branch block was mostly not seen in infants. Right axis deviation was found in 93 cases $(41.1 \%)$. Prolonged PR-interval was found in 64 (28.5\%). Fyler had also noted prolonged PR-interval in 10 per cent of ASD $2^{\circ}$ cases. There are two factors that contribute the prolongation of the PR-interval: (1) any large atrial septal defect altered a large segment of the anatomy of the atrial septum that might affect the three specific atrial pathway which conducted faster than surrounding atrial muscle; and (2) the right atrial enlargement required to accommodate the hemodynamic volume overload increases the distance of the SA node and the AV node. ${ }^{7,10}$

Chest x-ray in ASD showed moderate to marked cardiomegaly with increased pulmonary vascular markings, proportionate to the amount of shunt. ${ }^{3,7,22}$ In most cases, the pulmonary artery segment was prominent. ${ }^{\text {- }}$ $3,7,22$ In this series, cardiothoracic ratio of greater than 0,55 and increased vascular marking were seen in 94 cases $(41.4 \%)$ and 106 cases $(47.4 \%)$, respectively. When we divided the patients into 2 group with a cutoff point of 3 years (see Table 5), it became apparent that those abnormalities were mainly seen in older patients. Hoffman reported that large shunt might have no cardiomegaly.

The echocardiographic diagnosis of ASD has evolved to the point where it can be made with virtual certainty. ${ }^{3}$ Combined normal findings by $\mathrm{x}$-ray film and echocardiography appeared adequate for exclusion of ASD. ${ }^{14}$ ASD are best visualized using a subxiphoid view. In this series the defect could be visualized in all 177 cases (Table 5).

Supporting evidence for a shunt should always be sought. Reversal septal motion on the M-mode as manifestation of right ventricular dilatation could be detected in 34 cases (15.0\% of all cases). It is interesting to note that no single patient aged less than 3 years showed reversal septal motion. Right atrial enlargement and dilatation of the right ventricle that indicated volume loading due to the left-to-right shunt was found in 125 cases and 134 cases, respectively. Value of respiratory variations dimension by echocardiographic study in the identification of small $\mathrm{ASD}^{2}$ not requiring surgery had been reported. ${ }^{15}$ A normal right ventricular end-diastolic dimension during expiration (RVDDE) is very specific but not sensitive, a normal septal motion is very sensitive and moderately specific, and normal variation in right ventricular diastolic with respiration (RVDVR) is both very sensitive and specific. ${ }^{5}$ Doppler color flow mapping is especially useful in detecting shunt flow across an atrial defect. $^{3}$

Transesophageal echocardiography has overcome some of the limitations of the transthoracic approach. Transesophageal Doppler color flow imaging is extremely sensitive not only in detecting ASD but also in evaluating the size and the shunt flow volume. ${ }^{16}$ 
Tricuspid regurgitation is a determinant of the right to left shunt in patients with ASD even in the absence of the reversal of pressure gradient between the left and right atrium. ${ }^{16}$

Cardiac catheterization and surgical closure were performed in 36 patients (15.9\%) and 47 patients (20.8\%), respectively (Table 6). Most of the cardiac catheterization were performed before the advent of echocardiography. ${ }^{7,23,24}$ The pulmonary-systemic flow ratio $>2.5$ was found in most cases, and had a good correlation with the presence of mid diastolic tricuspid flow murmur. Pulmonary vascular resistance was normal in most cases. As has been practiced in most centers, the surgical closure was performed in last 11 cases without cardiac catheterization. To day the risk of cardiac surgery for $\operatorname{ASD} 2^{\circ}$ is virtually zero, but unfortunately the surgical mortality rate in this series was still high (8.5\%) (Table 8). Four patients died, consisted of one patient died on table of profuse bleeding and the 3 others deceased less than 24 hours after surgery of respiratory and congestive heart failure.

In view of high rate of spontaneous closure even of a large ASD, it seems advisable to defer elective surgical closure until after 2-3 years of age if successful medical management can be achieved. ${ }^{3,8}$ Most infants with symptomatic ASD may be managed medically, allowing sufficient time to observe whether spontaneous closure will occur. ${ }^{12}$ Vigorous medical management, including digitalis, diuretics, and antibiotics, were sufficient to maintain these infants during this critical first year permitting elective surgical repair later. ${ }^{10}$ In symptomatic infants who fail to respond to intensive medical therapy the defect is best closed immediately, both to improve the clinical condition and to prevent the development of further pulmonary vascular damage. Though pulmonary hypertension develops rarely in childhood, closure of the defect should not be postponed if there is any doubt that pulmonary arterial is normal. ${ }^{21}$ Double-umbrella devices that are inserted with a cardiac catheter are now used to close many ASDs. The desirability of avoiding intrathoracic dissection and opening the heart is obvious. ${ }^{3}$

\section{SUMMARY}

The following features can be summarized from our data:

1. ASD $2^{\circ}$ affected girls more than boys, the sex ratio was $1.5: 1$.

2. Typical auscultatory findings could be heard in most older cases.
3. In young infants with $\operatorname{ASD} 2^{\circ}$ the clinical findings were usually not specific, echocardiographic examination was usually needed to confirm the diagnosis.

4. Growth retardation, cardiomegaly, right bundle branch block, right ventricular hypertrophy, paradoxical ventricular septal motion, were common in large ASD $2^{\circ}$.

5. Simple closure of ASD $2^{\circ}$ was the procedure of choice.

\section{REFERENCES}

1. Feld RH, Edwards WD, Puga FJ, Seward JB, Weilman WH. Atrial septal defects and atrioventricular canal. In: Adams FH, Emmanouilides GC, eds. Moss' Heart disease in infants, children and adolescent; 3rd ed. Baltimore: Williams and Wilkins, 1983;118-34.

2. Berman LB, Zuberbuhler JR. Atrial septal defect. In: Anderson RH, Shinebourn EA, Macartney FJ, Tynan M, eds. Pediatric Cardiology, 1st ed. New York: Churchill Livingstone, 1987; 541-62.

3. Fyler DC. Nadas' pediatric cardiology. Singapore: Hanley Belfus, 1992; 513-24.

4. Perloff JK. The clinical recognition of congenital heart disease; 3rd ed. Philadelphia: Saunders, 1987; 272-349

5. Baum D, Beck R, Kodama A, Brown B. Early heart failure as cause of growth and tissue disorder in children with congenital heart disease. Circulation 1990; 62:1145-51.

6. Sastroasmoro S, Oesman IN, Madiyono B. Auskultasi jantung dan fonokardiografi, Naskah Lengkap Pendidikan Tambahan Berkala Ilmu '́iesehatan Anak ke XI. hal. 5-20 (Fakultas Kedokteran Universitas Indonesia, Jakarta 1985),

7. Madiyono B, Oesman IN, Sastroasmoro S, Sukman TP, Soelaiman EJ, Rachmad KB. Secundum atrial septal defect before and after surgery. Pediatr Indones 1989; 29 : 199-208.

8. Hunt CE, Lucas RV Jr. Symptomatic atrial septal defect in infancy. Circulation 1972; 47:1042-8.

9. Hoffman JIE, Rudolph AM, Danilowicz D. Left to right atrial shunt in infants. Am J Cardiol 1972; 30:868-75.

10. Dimich I, Steinfeld L, Park SC. Symptomatic atrial septal defect in infants. Am Heart J 1973; 85:601-4.

11. Tandon R, Edward JE. Atrial septal defect in infancy. Common association with other anomalies. Circulation 1974; 49:1005-10.

12. Mahoney LT, Truesdell SC, Krzmarzick TR, Lauer RM. Atrial septal defects that present in infancy. Am J Dis Child 1986; 140:1115-8.

13. Madiyono B, Oesman IN, Sastroasmoro S. Pemeriksaan ekokardiografi pada beberapa penyakit jantung bawaan. Naskah Lengkap Pendidikan Tambahan Berkala Ilmu Kesehatan Anak ke-XI, hal. 43-70 (Fakultas Kedokteran Universitas Indonesia, Jakarta 1985)

14. Egelblad H, Herning J, Efsen F, Wennevold A. Non-invasive diagnosis in clinically suspected atrial septal defect of secundum or sinus venosus type. Value of combining chest x-ray, phonocardiography, and M-mode echocardiogarphy. $\mathrm{Br}$ Heart J 1980; 44:117-21. 
15. Mauran P, Fouron JC, Carceller AM, et al. Value of respiratory variations of right ventricular dimension in the identification of small atrial septal defects (secundum type) not requiring surgery: An echocardiographic study. Am Heart J 1986; 112:548-53.

16. Kai H, Koyanagi S, Hirooka Y, et al. Right-to-left shunt across atrial septal defect related to tricuspid regurgitation: Assessment by transesophageal Doppler echocardiogarphy. Am Heart J 1994; 127:578-84.

17. Mehrizi A, Drash A. Growth disturbance in congenital heart disease. J Pediatr 1962; 61: 418-29.

18. Feidt RH, Stricler GB, Wiedman WH. Growth of children with congenital heart disease. Am J Dis Child 1969; 117: 573-9.

19. Suoninen P. Physical growth of children with congenital heart disease, pre and post operative study of 355 cases. Acta Paediatr Scand 1971; Suppl 255:1-45.

20. Chan KY, Tay JSH, Yip WCL, Wong HB. Growth retardation in children with congenital heart disease. J Singapore Paediatr Soc 1987; 29: 185-193.
21. Haworth SG. Pulmonary vascular disease in secundum atrial septal defect in childhood. Am J Cardiol 1982; 51:265-72.

22. Tamaela LA. Penilaian X-foto polos pada penyakit jantung bawaan, Naskah Lengkap Pendidikan Tambahan Berkala Ilmu Kesehatan Anak ke XI, hal. 5-20 (Fakultas Kedokteran Universitas Indonesia, Jakarta 1985).

23. Madiyono B, Trisnohadi HB, Affandi MB. His bundle electrocardiogram in children with secundum atrial septal defect. Paediatr Indones 1981; 21:1-10.

24. Oesman IN, Madiyono B, Sastroasmoro S. Kateterisasi jantung dan angiokardiografi pada penyakit jantung bawaan, Naskah Lengkap Pendidikan Tambahan Berkala Ilmu Kesehatan Anak ke XI, hal. 71-84 (Fakultas Kedokteran Universitas Indonesia, Jakarta 1985).

25. Rachmad KB. Tindakan pembedahan jantung pada penyakit jantung bawaan; Naskah Lengkap Pendidikan Tambahan Berkala Ilmu Kesehatan Anak ke XI, Hal. 88-96 (Fakultas Kedokteran Universitas Indonesia, Jakarta 1985)

26. Graham TD. When to operate on a child with congenital heart disease. Pediatr Clin N Am 1984; 31:1275-91. 